\title{
Physiology and production of naturally-colored cotton under irrigation strategies using salinized water
}

\author{
Lauriane Almeida dos Anjos Soares ${ }^{(1)}$, Pedro Dantas Fernandes ${ }^{(1)}$, Geovani Soares de Lima ${ }^{(1)}$, \\ Marcos Eric Barbosa Brito(2), Ronaldo do Nascimento ${ }^{(1)}$ and Nair Helena Castro Arriel(3)
}

\begin{abstract}
(1)Universidade Federal de Campina Grande, Campus Campina Grande, Rua Aprígio Veloso, no 882, Bairro Universitário, CEP58429-900CampinaGrande,PB,Brazil.E-mail:laurispo.agronomia@gmail.com,pdantas@pq.cnpq.br, geovanisoareslima@gmail.com, ronaldon453@gmail.com (2)Universidade Federal de Sergipe, Campus do Sertão, Rodovia Engenheiro Jorge Neto, Km 3, s/no, CEP 49680-000 Nossa Senhora da Glória, SE, Brazil. E-mail: marcosericbb@yahoo.com.br ${ }^{(3)}$ Embrapa Algodão, Rua Osvaldo Cruz, no 1.143, Centenário, CEP 58428-095 Campina Grande, PB, Brazil. E-mail: nair.arriel@embrapa.br
\end{abstract}

\begin{abstract}
The objective of this work was to evaluate the effects of irrigation management strategies, using low $\left(0.8 \mathrm{dS} \mathrm{m}^{-1}\right)$ and high $\left(9.0 \mathrm{dS} \mathrm{m}^{-1}\right)$ salinity water, on the physiological processes, production variables, and fiber productivity of naturally-colored cotton (Gossypium hirsutum) genotypes during different phenological stages. Three naturally-colored cotton cultivars (BRS Rubi, BRS Topázio, and BRS Safira) were subjected to seven irrigation management strategies, in a $3 \times 7$ factorial arrangement, in a randomized complete block design with three replicates. Plants were cultivated in pots in a protected environment. Gas exchange, chlorophyll $a$ fluorescence, fiber production, and productivity and yield variables were evaluated. Salt stress causes greater reductions in gas exchange in natural cotton plants during the production stage. Plume cotton production is not compromised by the use of highly salinized water during the initial developmental stages of naturallycolored cotton
\end{abstract}

Index terms: Gossypium hirsutum, fiber productivity, quantum yield, salinity.

\section{Fisiologia e produção de algodoeiro naturalmente colorido submetido a estratégias de irrigação com água salinizada}

\begin{abstract}
Resumo - O objetivo deste trabalho foi avaliar os efeitos de estratégias de manejo da irrigação, com água de baixa $\left(0,8 \mathrm{dS} \mathrm{m}^{-1}\right)$ e alta salinidade $\left(9,0 \mathrm{dS} \mathrm{m}^{-1}\right)$, sobre os processos fisiológicos, as variáveis de produção e o rendimento de fibras de genótipos de algodoeiro (Gossypium hirsutum) naturalmente colorido, em diferentes fases fenológicas. Foram avaliadas três cultivares de algodoeiro colorido (BRS Rubi, BRS Topázio e BRS Safira), submetidas a sete estratégias de manejo de irrigação, em arranjo fatorial $3 \times 7$, em delineamento de blocos ao acaso, com três repetições. As plantas foram cultivadas em vasos, em ambiente protegido. Foram avaliadas trocas gasosas, fluorescência da clorofila $a$, e variáveis de produção e de rendimento de fibra. $\mathrm{O}$ estresse salino ocasiona maiores reduções nas trocas gasosas do algodoeiro durante a fase de formação da produção. A produção de algodão em pluma não é comprometida pelo uso de água de alta salinidade nas fases iniciais de desenvolvimento do algodoeiro colorido naturalmente.
\end{abstract}

Termos para indexação: Gossypium hirsutum, rendimento de fibra, eficiência quântica, salinidade.

\section{Introduction}

Salinity is considered one of the main limiting factors for agricultural productivity and sustainability, especially in arid and semiarid regions characterized by elevated evapotranspiration demand, reduced rainfall, reduced water availability, and soil resources with variable salt content (Dong et al., 2010). In these regions, it is essential to generate technology that enables the use of water with salinity restrictions for crop irrigation, taking into account that highly salinized water increases soil salinity due to ion accumulation in the root zone (Letey \& Feng, 2007).

In general, decreases in the productivity of plants in highly salinized environments can be attributed, in part, to limitations in the physiological processes of the plant, mainly gas exchange and $a$ chlorophyll fluorescence because of stomatal closure and a reduction in carbon fixation activity (Zhang et al., 2014; Rady et al., 2016). Furthermore, salinity leads 
to nutritional imbalances, since excessive amounts of $\mathrm{Na}^{+}$in the soil solution result in absorption disorders that affect other nutrients, particularly $\mathrm{Ca}, \mathrm{Mg}$, and $\mathrm{K}$ (Rosales et al., 2012).

Cotton (Gossypium hirsutum L.) plants are capable of adapting to semiarid environments due to their tolerance to salt stress of up to $5.1 \mathrm{dS} \mathrm{m}^{-1}$ for irrigation water (Ayers \& Westcot, 1999; Oliveira et al., 2013). Despite this tolerance, several researchers have reported negative effects of salinity on naturally-colored cotton plants (Santos et al., 2016; Lima et al., 2017; Silva et al., 2017). It should be noted, however, that the level of tolerance to salinity may vary among species and/or genotypes of a species, or even among the phenological stages of a same genotype (Neves et al., 2009).

Previous studies on the use of salinized water for cotton irrigation have evaluated in which developmental stage the physiological processes and, consequently, cotton production were less affected (Chen et al., 2010; Zhang et al., 2013). In white plume cotton plants, different results were obtained according to genotype, soil, and climate conditions; at times, plants were more susceptible during germination and initial plant growth and, at others, during flowering and fructification (Khorsandi \& Anagholi, 2009).

However, the effects of salinity during each developmental stage of cotton plants and the reproductive compensation after salt stress exposure are still poorly understood. This shows the importance of studies on the recovery of cotton plants after salt stress during each developmental stage, from germination to production (Ashraf et al., 2008; Shaheen \& Shahbaz, 2012). Physiological and production aspects should be considered when selecting new tolerant materials; salt ions, for example, may affect the photosynthetic and production apparatuses, which may be related to cotton fiber productivity.

The objective of this work was to evaluate the effects of irrigation management strategies, using low $\left(0.8 \mathrm{dS} \mathrm{m}^{-1}\right)$ and high $\left(9.0 \mathrm{dS} \mathrm{m}^{-1}\right)$ salinity water, on the physiological processes, production variables, and fiber productivity of naturally-colored cotton genotypes during different phenological stages.

\section{Materials and Methods}

The experiment was conducted in a protected environment of the center of technology and natural resources of Universidade Federal de Campina Grande, located in the municipality of Campina Grande, in the state of Paraíba, Brazil (07 $15^{\circ} 18^{\prime \prime} \mathrm{S}, 35^{\circ} 52^{\prime} 28^{\prime \prime} \mathrm{W}$, at an average altitude of $550 \mathrm{~m}$ ).

Three cotton plant genotypes - BRS Rubi, BRS Topázio, and BRS Safira - were subjected to different irrigation management strategies using salinized water, in the following phenological stages: vegetative (A), from the emission of the first leaf until the anthesis of the first flower; flowering (B), from the first anthesis until the opening of the first boll; and fructification/ production (C), from the opening of the first boll until harvest.

A total of seven irrigation management strategies were applied, using water with two electrical conductivity levels $(\mathrm{ECw})$ : low $\left(\mathrm{ECw}=0.8 \mathrm{dS} \mathrm{m}^{-1}\right)$ and high salinity $\left(9 \mathrm{dS} \mathrm{m}^{-1}\right)$, according to Lima et al. (2016). The different strategies evaluated were: $A_{1} B_{1} C_{1}$, irrigation with water with low $\mathrm{ECw}$ during the entire cycle, identified by index 1 in the phenological stages; $\mathrm{A}_{2} \mathrm{~B}_{1} \mathrm{C}_{1}$, salt stress during the vegetative stage, represented by index 2 during stage A, with plants receiving $\mathrm{ECw}=9 \mathrm{dS} \mathrm{m}^{-1}$ water from 16 days after sowing (DAS) until flowering at 37 DAS, followed by irrigation using water with low $\mathrm{ECw}$ until the end of cycle; $\mathrm{A}_{1} \mathrm{~B}_{2} \mathrm{C}_{1}$, salt stress during the flowering stage, i.e., irrigation with water with high $\mathrm{ECw}$ from 37 DAS until the beginning of fructification at 59 DAS and with water with low $\mathrm{ECw}$ during the remaining stages; $\mathrm{A}_{1} \mathrm{~B}_{1} \mathrm{C}_{2}$, use of water with low $\mathrm{ECw}$ during the vegetative and flowering stages, and with high $\mathrm{ECw}$ until the end of the cycle at 113 DAS; $A_{2} B_{1} C_{2}$, irrigation with water with high $\mathrm{ECw}$ during the vegetative and fructification stages, and without salinity during flowering; $\mathrm{A}_{2} \mathrm{~B}_{2} \mathrm{C}_{1}$, irrigation with salinized water during the vegetative and flowering stages, and with water with low $\mathrm{ECw}$ during fructification; and $\mathrm{A}_{1} \mathrm{~B}_{2} \mathrm{C}_{2}$, water with low $\mathrm{ECw}$ during the vegetative stage and irrigation with water with high $\mathrm{ECw}$ during the flowering and production stages. The experimental design was a randomized complete block in a $3 \times 7$ factorial arrangement, totaling 21 treatments with three replicates and three plants per plot.

The plants were cultivated in 20 -L plastic pots (height of $35 \mathrm{~cm}$, top diameter of $31 \mathrm{~cm}$, and bottom diameter of $20 \mathrm{~cm}$ ), lined with a fine screen at the bottom to avoid soil loss; a hose was also placed at the bottom and coupled to a container to collect drainage water. A 3-cm layer of gravel and $24.5 \mathrm{~kg}$ of previously screened Neossolo Regolítico Eutrófico (Santos et al., 
2013), i.e., Entisol, with sandy loam texture, were placed on the screen. The soil physical-hydraulic attributes were: $38.59 \%$ total porosity; 11.48 and 2.41 $\mathrm{kPa}$ water content at field capacity $(33.42 \mathrm{kPa})$ and permanent wilting point $(1,519.5 \mathrm{kPa})$, respectively; and 1.51 available water. The other chemical and physical attributes are presented in Table 1 . The pots were arranged in simple rows spaced at $1.0 \mathrm{~m}$ from each other; the spacing within each row was $0.6 \mathrm{~m}$.

Base dressing was performed using N-P-K, according to recommendations for experiments in pots (Novais et al., 1991); a total of $100 \mathrm{mg} \mathrm{kg}-1$ $\mathrm{N}$ as ammonium sulfate, $300 \mathrm{mg} \mathrm{kg}^{-1} \mathrm{P}$ as single superphosphate, and $150 \mathrm{mg} \mathrm{kg}^{-1} \mathrm{~K}$ as potassium chloride was applied. The base dressing provided the full amount of $\mathrm{P}$, but only $1 / 3$ of $\mathrm{N}$ and $\mathrm{K}$; the other $2 / 3$ were applied through irrigation water at 45 and 65 DAS. In addition, $500 \mathrm{~g}$ worm castings were added to each pot. Foliar fertilization was done at the beginning of the flowering stage at $45 \mathrm{DAS}$, in order to improve plant nutrition, using a commercial product containing: $0.05 \% \mathrm{~B}, 0.5 \% \mathrm{Cu}, 0.5 \% \mathrm{Fe}, 0.05 \% \mathrm{Mn}, 0.02 \% \mathrm{Mo}$, and $0.5 \% \mathrm{Zn}$.

Table 1. Chemical and physical attributes of the soil used in the experiment, before the treatments were applied ${ }^{(1)}$.

\begin{tabular}{|c|c|}
\hline Attributes & Value \\
\hline $\mathrm{pH}_{\mathrm{sp}}$ & 5.8 \\
\hline $\operatorname{SOM}\left(\right.$ dag $\left._{k^{-1}}\right)$ & 21.20 \\
\hline $\mathrm{P}\left(\mathrm{mg} \mathrm{kg}^{-1}\right)$ & 45 \\
\hline $\mathrm{K}^{+}\left(\mathrm{cmol}_{\mathrm{c}} \mathrm{kg}^{-1}\right)$ & 0.18 \\
\hline $\mathrm{Na}^{+}\left(\mathrm{cmol}_{\mathrm{c}} \mathrm{kg}^{-1}\right)$ & 0.37 \\
\hline $\mathrm{Ca}^{2+}\left(\mathrm{cmol}_{\mathrm{c}} \mathrm{kg}^{-1}\right)$ & 2.37 \\
\hline $\mathrm{Mg}^{2+}\left(\mathrm{cmol}_{\mathrm{c}} \mathrm{kg}^{-1}\right)$ & 3.09 \\
\hline $\mathrm{Al}^{3+}+\mathrm{H}^{+}\left(\mathrm{cmol}_{\mathrm{c}} \mathrm{kg}^{-1}\right)$ & 1.78 \\
\hline ECse $\left(\mathrm{dS} \mathrm{m}^{-1}\right)$ & 0.20 \\
\hline \multicolumn{2}{|l|}{ Particle size fraction } \\
\hline Sand $\left(\mathrm{g} \mathrm{kg}^{-1}\right)$ & 808.6 \\
\hline Silt $\left(\mathrm{g} \mathrm{kg}^{-1}\right)$ & 80.5 \\
\hline Clay $\left(\mathrm{g} \mathrm{kg}^{-1}\right)$ & 110.9 \\
\hline Textural class & Sandy loam \\
\hline Density $\left(\mathrm{kg} \mathrm{dm}^{-3}\right)$ & 1.67 \\
\hline
\end{tabular}

(1) $\mathrm{pH}_{\mathrm{SP}}, \mathrm{pH}$ of the saturation paste; $\mathrm{SOM}$, soil organic matter determined by the Walkley-Black wet digestion method; $\mathrm{K}^{+}$and $\mathrm{Na}^{+}$extracted using 1 mol L-1 $\mathrm{NH}_{4} \mathrm{OAc}, \mathrm{pH} 7.0$; $\mathrm{Ca}^{2+}$ and $\mathrm{Mg}^{2+}$ extracted with $1 \mathrm{~mol} \mathrm{~L}^{-1} \mathrm{KCl}, \mathrm{pH}$ 7.0; ECse, electrical conductivity of the saturation extract.
The water used for low-salinity irrigation $\left(0.8 \mathrm{dS} \mathrm{m}^{-1}\right)$ was obtained by diluting the water supplied by the public system of Campina Grande, in the state of Paraíba, Brazil, with rain water; the preparation of the water with high $\mathrm{ECw}\left(9.0 \mathrm{dS} \mathrm{m}^{-1}\right)$ and of the irrigation managements was similar to that described by Lima et al. (2016). Sowing was carried out after soil moisture was elevated to maximum retention in all experimental units, using low-salinity water $\left(0.8 \mathrm{dS} \mathrm{m}^{-1}\right)$ and five seeds per pot at a $3-\mathrm{cm}$ depth. Thinning was performed at 30 DAS, and only one plant was kept in each pot.

Physiological variables were evaluated at 70 and 93 DAS, when plants reached full fructification and all salinity management strategies could be included in the statistical analysis, since all salinized treatments had already started. The following parameters were assessed on the third leaf from the top of the plant: $\mathrm{CO}_{2}$ assimilation rate $\left(\mu \mathrm{mol} \mathrm{m} \mathrm{m}^{-2} \mathrm{~s}^{-1}\right)$, transpiration $(\mathrm{mmol}$ $\left.\mathrm{H}_{2} \mathrm{O} \mathrm{m}^{-2} \mathrm{~s}^{-1}\right)$, stomatal conductance $\left(\mathrm{mol} \mathrm{H}_{2} \mathrm{O} \mathrm{m}^{-2} \mathrm{~s}^{-1}\right.$ ), and inner $\mathrm{CO}_{2}$ concentration $\left(\mu \mathrm{mol} \mathrm{mol}{ }^{-1}\right)$ using the LCpro $^{+}$gas exchange meter (ADC Bioscientific Ltd., Hoddesdon, United Kingdom). The obtained data were used to estimate the instantaneous water use efficiency (WUE) $\left(\mathrm{CO}_{2}\right.$ assimilation rate/transpiration) $\left[\left(\mu \mathrm{mol} \mathrm{m} \mathrm{s}^{-1}\right)\left(\mathrm{mmol} \mathrm{H} \mathrm{H}_{2} \mathrm{O} \mathrm{m}^{-2} \mathrm{~s}^{-1}\right)^{-1}\right]$ and the intrinsic carboxylation efficiency (iCE) $\left(\mathrm{CO}_{2}\right.$ assimilation rate/ inner $\mathrm{CO}_{2}$ concentration $)\left[\left(\mu \mathrm{mol} \mathrm{m}^{-2} \mathrm{~s}^{-1}\right)\left(\mu \mathrm{mol} \mathrm{mol}^{-1}\right)^{-1}\right]$.

At 93 DAS, the same leaves used for the gas exchange analysis were clipped, and, after adaptation to the dark for $30 \mathrm{~min}$, $a$ chlorophyll was determined. Initial fluorescence (Fo), maximum fluorescence (Fm), variable fluorescence (Fm-Fo), and quantum yield of photosystem II ( Fv/Fm) were also obtained using the pulse-modulated fluorometer, model OS5p-Opti Science (Hansatech Instruments Ltd, Norfolk, United Kingdom) (Maxwell \& Johnson, 2000; Konrad et al., 2005).

Production was quantified by the harvest of bolls until 113 DAS. Treatments were applied until the end of cycle, and plume mass and plume fiber productivity were determined using the equation described by Albrecht et al. (2009): FP $(\%)=F M / T M \times 100$, where FP is fiber productivity, FM is cotton fiber mass $(\mathrm{g})$, and TM is total boll mass ( $\mathrm{g}$ ).

Data were evaluated using the F-test, and, when significant, means were compared by Scott-Knott's grouping test, at $5 \%$ probability, for salinity strategies, and by Tukey's test, also at 5\% probability, for cotton plant genotypes (Ferreira, 2011). 


\section{Results and Discussion}

Based on the analysis of variance (Table 2), salinity management strategies had significant effects on stomatal conductance, transpiration, $\mathrm{CO}_{2}$ assimilation rate, WUE, inner $\mathrm{CO}_{2}$ concentration, and $\mathrm{iCE}$ at 70 and 93 DAS, when plants were in full fructification. Among cotton genotypes, only inner $\mathrm{CO}_{2}$ concentration and iCE differed at 93 DAS. The interaction between factors (management strategies $\times$ genotypes) showed no significant effects, i.e., gas exchange did not vary according to the stage in which the genotypes were subjected to salt stress, indicating that the negative effects of irrigation water salinity on cotton plants are significantly more intense during prolonged exposure or exposure during the entire crop cycle (Jafri \& Ahmad, 2002).

Stomatal conductance at 70 DAS (Figure 1 A) showed reductions of $61.13,47.19$, and $67.27 \%$ in plants irrigated with salinized water in the $\mathrm{A}_{1} \mathrm{~B}_{2} \mathrm{C}_{1}, \mathrm{~A}_{2} \mathrm{~B}_{2} \mathrm{C}_{1}$, and $\mathrm{A}_{1} \mathrm{~B}_{2} \mathrm{C}_{2}$ management strategies, respectively, when compared with plants irrigated with low-salinity water in $\mathrm{A}_{1} \mathrm{~B}_{1} \mathrm{C}_{1}$. However, there was an average recovery in stomatal conductance of 0.13 and 0.19 mol m$~_{-2} \mathrm{~s}^{-1}$, respectively, using the $\mathrm{A}_{1} \mathrm{~B}_{2} \mathrm{C}_{1}$ and $\mathrm{A}_{2} \mathrm{~B}_{2} \mathrm{C}_{1}$ management strategies at 93 DAS. It should be pointed out that these plants had already been irrigated with low-salinity water $\left(0.8 \mathrm{dS} \mathrm{m}^{-1}\right)$ during 34 days (Figure 1 A). According to Gratan et al. (2004), the tolerance of plants to salinity usually increases with age, after the vegetative growth stages. Similar results were observed for barley (Hordeum vulgare L.) by Pandya et al. (2005), cowpea [Vigna unguiculata (L.) Walp.] by Neves et al. (2009), and white-plume cotton (Gossypium hirsutum L.) by Zhang et al. (2013).

As a result of partial stomatal closure, when plants were subjected to salt stress, foliar transpiration showed similar reductions (Figure $1 \mathrm{~B}$ ) of 50, 36.13, and 51.75\% for $\mathrm{A}_{1} \mathrm{~B}_{2} \mathrm{C}_{1}, \mathrm{~A}_{2} \mathrm{~B}_{2} \mathrm{C}_{1}$, and $\mathrm{A}_{1} \mathrm{~B}_{2} \mathrm{C}_{2}$, respectively, at 70 DAS, compared with $\mathrm{A}_{1} \mathrm{~B}_{1} \mathrm{C}_{1}$. At 93 DAS, however, reductions of $54.15,58.84$, and $43.53 \%$ in transpiration were observed for $\mathrm{A}_{1} \mathrm{~B}_{1} \mathrm{C}_{2}, \mathrm{~A}_{2} \mathrm{~B}_{1} \mathrm{C}_{2}$, and $\mathrm{A}_{1} \mathrm{~B}_{2} \mathrm{C}_{2}$, respectively. Similarly, Lima et al. (2017) verified that water salinity $\left(9.1 \mathrm{dS} \mathrm{m}^{-1}\right)$ reduced the stomatal conductance and foliar transpiration of 'BRS Rubi' in 33.20 and $27.72 \%$, respectively, during the production stage, at $83 \mathrm{DAS}$; the authors also associated these reductions with partial stomatal closure, as well as with osmotic and ionic toxicity effects on the metabolism of plants subjected to salinity conditions.

Table 2. Analysis of variance of the physiological parameters evaluated for naturally-colored cotton (Gossypium hirsutum) at 70 and 93 days after sowing (DAS) according to different salinity management strategies and genotypes.

\begin{tabular}{|c|c|c|c|c|c|c|c|c|}
\hline \multirow[t]{2}{*}{ Variable $^{(1)}$} & \multirow[t]{2}{*}{$\mathrm{DF}$} & Mean square & \multirow[t]{2}{*}{$\mathrm{DF}$} & Mean square & \multirow[t]{2}{*}{$\mathrm{DF}$} & Mean square & \multirow{2}{*}{$\begin{array}{l}\mathrm{CV} \\
(\%) \\
\end{array}$} & \multirow{2}{*}{$\begin{array}{c}\text { Overall } \\
\text { mean }\end{array}$} \\
\hline & & Management strategy (MS) & & Genotype (G) & & MS x G & & \\
\hline & \multicolumn{8}{|c|}{70 days after sowing (DAS) } \\
\hline gs & 6 & $0.071 * *$ & 2 & $0.001^{\mathrm{ns}}$ & 12 & $0.0009^{\mathrm{ns}}$ & 21.78 & 0.19 \\
\hline $\mathrm{E}$ & 6 & $16.718 * *$ & 2 & $0.296^{\mathrm{ns}}$ & 12 & $0.350^{\mathrm{ns}}$ & 23.74 & 4.20 \\
\hline A & 6 & $249.59 * *$ & 2 & $9.723^{\mathrm{ns}}$ & 12 & $3.880^{\mathrm{ns}}$ & 14.66 & 17.57 \\
\hline WUE & 6 & $1.010 * *$ & 2 & $0.287^{\mathrm{ns}}$ & 12 & $0.100^{\mathrm{ns}}$ & 19.34 & 4.42 \\
\hline $\mathrm{Ci}$ & 6 & $2,587.851^{* *}$ & 2 & $659.377^{\mathrm{ns}}$ & 12 & $385.435^{\mathrm{ns}}$ & 18.42 & 147.72 \\
\hline \multirow[t]{2}{*}{$\mathrm{iCE}$} & 6 & $0.0008^{* *}$ & 2 & $0.0003^{\text {ns }}$ & 12 & $0.0005^{\mathrm{ns}}$ & 27.35 & 0.12 \\
\hline & \multicolumn{8}{|c|}{93 days after sowing (DAS) } \\
\hline gs & 6 & $0.033 * *$ & 2 & $0.0004^{\mathrm{ns}}$ & 12 & $0.0002^{\mathrm{ns}}$ & 20.96 & 0.13 \\
\hline $\mathrm{E}$ & 6 & $10.442 * *$ & 2 & $0.072^{\mathrm{ns}}$ & 12 & $0.084^{\mathrm{ns}}$ & 22.1 & 2.98 \\
\hline A & 6 & $109.087 * *$ & 2 & $6.465^{\mathrm{ns}}$ & 12 & $2.272^{\mathrm{ns}}$ & 13.93 & 11.90 \\
\hline WUE & 6 & $1.882 * *$ & 2 & $0.868^{\mathrm{ns}}$ & 12 & $0.230^{\mathrm{ns}}$ & 14.45 & 4.428 \\
\hline $\mathrm{Ci}$ & 6 & $6,642.769 * *$ & 2 & $1,652.994^{*}$ & 12 & $378.708^{\mathrm{ns}}$ & 13.51 & 163.841 \\
\hline $\mathrm{iCE}$ & 6 & $0.001 * *$ & 2 & $0.001 * *$ & 12 & $0.0004^{\mathrm{ns}}$ & 24.06 & 0.0765 \\
\hline
\end{tabular}

${ }^{(1)} \mathrm{gs}$, stomatal conductance; E, transpiration; $\mathrm{A}, \mathrm{CO}_{2}$ assimilation rate; WUE, instantaneous water use efficiency; $\mathrm{Ci}$, inner $\mathrm{CO}_{2}$ concentration; iCE, intrinsic carboxylation efficiency; DF, degree of freedom; and CV, coefficient of variation. * and **Significant by the F-test, at 5 and $1 \%$ probability,

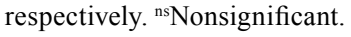


The $\mathrm{CO}_{2}$ assimilation rate was compromised for plants irrigated with highly salinized water $\left(9.0 \mathrm{dS} \mathrm{m}^{-1}\right)$, and the most significant reductions were observed at 93 DAS for the $A_{1} B_{1} C_{2}, A_{2} B_{1} C_{2}$, and $A_{1} B_{2} C_{2}$ management strategies (Figure $1 \mathrm{C}$ ). Therefore, when salt stress was applied during fructification, there was an increase in the resistance to $\mathrm{CO}_{2}$ diffusion due to a decrease in stomatal conductance, as previously discussed.
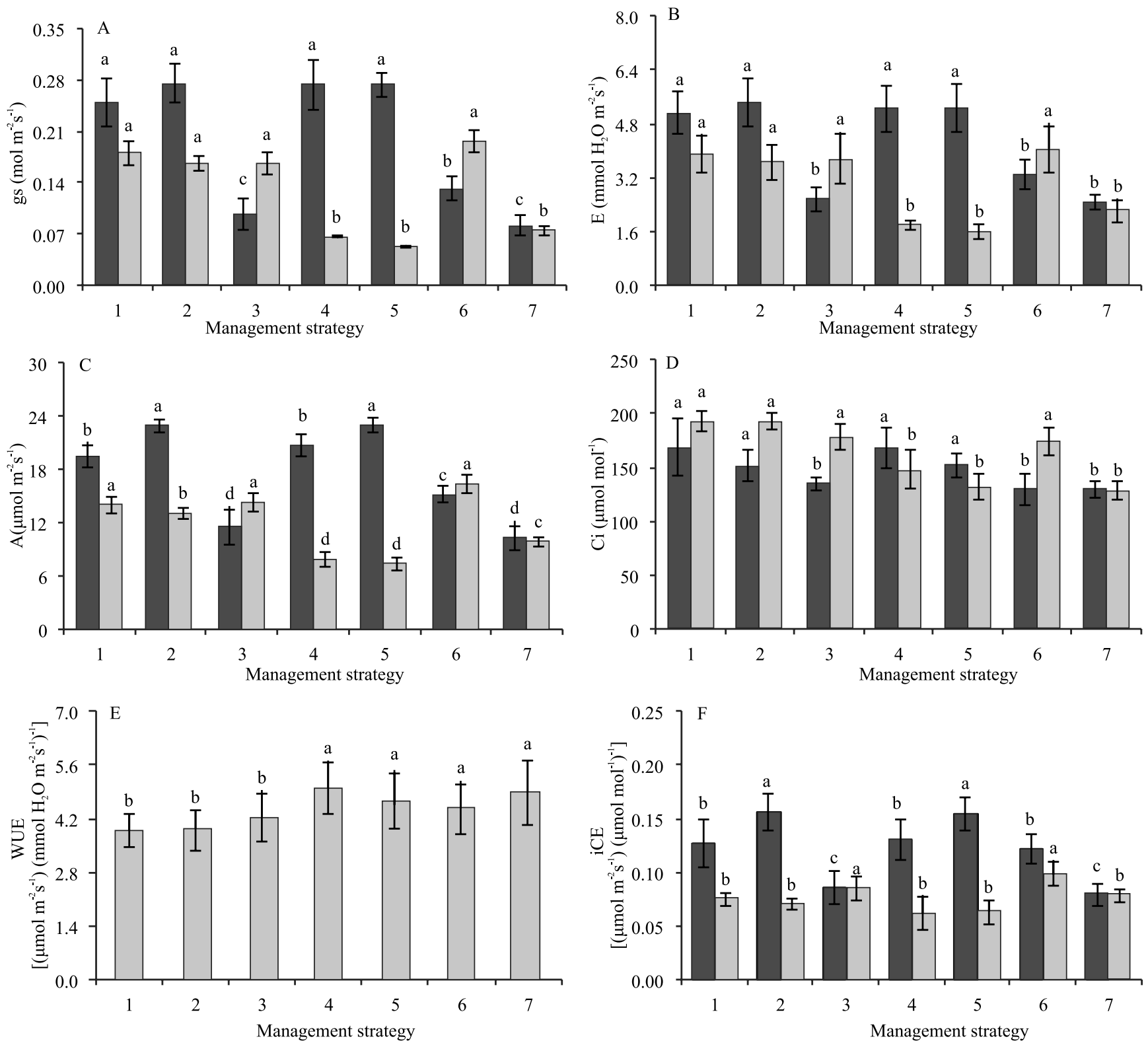

70 DAS $\square 93$ DAS

Figure 1. Means related to: A, stomatal conductance (gs); B, transpiration (E); $\mathrm{C}, \mathrm{CO}_{2}$ assimilation rate (A); D, inner $\mathrm{CO}_{2}$ concentration (Ci); E, instant water usage effectiveness (WUE); and F, instant carboxylation efficiency (iCE) in naturallycolored cotton (Gossypium hirsutum) plants at 70 and 93 days after sowing (DAS) under different salinity management strategies. Distinct lowercase letters indicate significant differences among salinity management strategies by Scott-Knott's test, at 5\% probability. Bars represent the standard error of the mean (n=9). 1, $\mathrm{A}_{1} \mathrm{~B}_{1} \mathrm{C}_{1} ; 2, \mathrm{~A}_{2} \mathrm{~B}_{1} \mathrm{C}_{1} ; 3, \mathrm{~A}_{1} \mathrm{~B}_{2} \mathrm{C}_{1} ; 4, \mathrm{~A}_{1} \mathrm{~B}_{1} \mathrm{C}_{2} ; 5$, $\mathrm{A}_{2} \mathrm{~B}_{1} \mathrm{C}_{2} ; 6, \mathrm{~A}_{2} \mathrm{~B}_{2} \mathrm{C}_{1} ;$ and $7, \mathrm{~A}_{1} \mathrm{~B}_{2} \mathrm{C}_{2}$, where $\mathrm{A}_{1}, \mathrm{~B}_{1}, \mathrm{C}_{1}$ represent no salinity during the vegetative, flowering, and fructification stages, and $\mathrm{A}_{2}, \mathrm{~B}_{2}, \mathrm{C}_{2}$, salinity during the vegetative, flowering, and fructification stages. 
Desingh \& Kanagaraj (2007) also reported a decrease in $\mathrm{CO}_{2}$ assimilation while evaluating the AryaAnubam and LRA-5166 cotton varieties subjected to different salinity levels -0 (control), 50, 100, and 150 mmol L-1 NaCl, $\mathrm{MgSO}_{4}$, and $\mathrm{CaCl}_{2}$, respectively - at 50 DAS, confirming the negative effect of salinity on cotton plants.

A higher inner $\mathrm{CO}_{2}$ concentration was observed for $\mathrm{A}_{1} \mathrm{~B}_{1} \mathrm{C}_{1}$ using $168.55 \mu \mathrm{mol} \mathrm{mol}{ }^{-1}$, but it did not differ significantly from that of $\mathrm{A}_{2} \mathrm{~B}_{1} \mathrm{C}_{1}, \mathrm{~A}_{1} \mathrm{~B}_{1} \mathrm{C}_{2}$, and $\mathrm{A}_{2} \mathrm{~B}_{1} \mathrm{C}_{2}$ (Figure $1 \mathrm{D}$ ). Partial stomatal closure at 93 DAS caused a decrease in foliar transpiration and in inner $\mathrm{CO}_{2}$ concentration in $\mathrm{A}_{1} \mathrm{~B}_{1} \mathrm{C}_{2}$ and $\mathrm{A}_{2} \mathrm{~B}_{1} \mathrm{C}_{2}$, when salinized water was applied during the production stage (Figure $1 \mathrm{D}$ ). These results are probably related to the decrease in the potential energy of water in the roots and/or in the transportation of abscisic acid to the leaves, resulting in increased stomatal resistance and decreased carbon concentration in the substomatal chamber (inner $\mathrm{CO}_{2}$ concentration). This is explained by the direct relationship between gas exchange (with implicit $\mathrm{CO}_{2}$ absorption) and water loss, in which stomatal closure results in a reduction in transpiration and, consequently, in a lower inner $\mathrm{CO}_{2}$ concentration (Shimazaki et al., 2007).

In alignment with the results obtained for stomatal conductance, transpiration, and $\mathrm{CO}_{2}$ assimilation, a higher WUE was observed at 93 DAS (Figure 1 E) for $A_{1} B_{1} C_{2}, A_{2} B_{1} C_{2}, A_{2} B_{2} C_{1}$, and $A_{1} B_{2} C_{2}$, with an average of $4.69\left[\left(\mu \mathrm{mol} \mathrm{m} \mathrm{m}^{-2} \mathrm{~s}^{-1}\right)\left(\mathrm{mmol} \mathrm{H}_{2} \mathrm{O} \mathrm{m}^{-2} \mathrm{~s}^{-1}\right)^{-1}\right]$. Therefore, plants that are more capable of increasing water usage under salinity conditions possibly show higher tolerance to salt stress during these stages, because reductions in water consumption result in a reduction in the absorption of specific ions, avoiding toxic effects on the plant (Nobre et al., 2014).

A higher iCE due to salinized water (Figure $1 \mathrm{E}$ ) was observed for $A_{2} B_{1} C_{1}$ and $A_{2} B_{1} C_{2}$ at 70 DAS, and for $\mathrm{A}_{1} \mathrm{~B}_{2} \mathrm{C}_{1}$ and $\mathrm{A}_{2} \mathrm{~B}_{2} \mathrm{C}_{1}$ at $93 \mathrm{DAS}$, notably during the vegetative and flowering stages, in which the $\mathrm{A}_{2} \mathrm{~B}_{2} \mathrm{C}_{1}$ management strategy showed an average of 0.098 $\left[\left(\mu \mathrm{mol} \mathrm{m} \mathrm{s}^{-2}\right)\left(\mu \mathrm{mol} \mathrm{mol}^{-1}\right)^{-1}\right]$ at $93 \mathrm{DAS}$. The values obtained for transpiration, $\mathrm{CO}_{2}$ assimilation rate, and instant carboxylation were within the variation range reported for cotton plants (Zhang et al., 2014; Lima et al., 2017), i.e., the photosynthetic apparatus was not compromised by stress during the initial crop developmental stages.
Genotype data analysis at 93 DAS indicated higher internal $\mathrm{CO}_{2}$ concentration (Figure $2 \mathrm{~A}$ ) for 'BRS Topázio' $\left(172.40 \mu \mathrm{mol} \mathrm{mol}^{-1}\right)$ than for the 'BRS Rubi' $\left(164.65 \mu \mathrm{mol} \mathrm{mol}^{-1}\right)$ and 'BRS Safira' $\left(154.69 \mu \mathrm{mol} \mathrm{mol}^{-1}\right)$ genotypes. The average iCE values observed for 'BRS Rubi' and 'BRS Safira', however, were 0.085

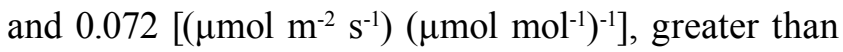
that observed for 'BRS Topázio' (Figure $2 \mathrm{~B}$ ). This is probably attributed to the low $\mathrm{CO}_{2}$ assimilation in the substomatal chamber of 'BRS Rubi' and 'BRS Safira'; however, the obtained values are higher than the average of $\left.0.03\left[\left(\mu \mathrm{mol} \mathrm{m} \mathrm{s}^{-2}\right)(\mu \mathrm{mol} \mathrm{ol})^{-1}\right)^{-1}\right] \mathrm{iCE}$ found by Pereira (2012) for these same genotypes.

Regarding fluorescence, no significant differences were verified among the naturally-colored cotton genotypes for photosynthetic apparatus efficiency
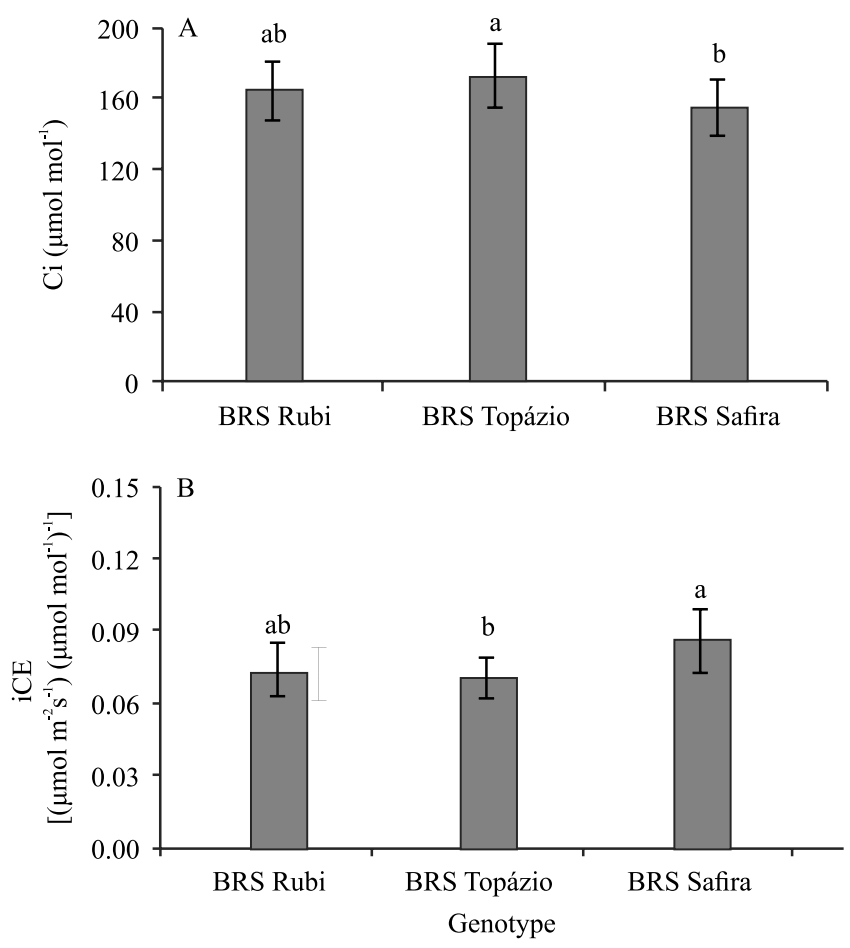

Figure 2. Means related to: $\mathrm{A}$, internal $\mathrm{CO}_{2}$ concentration (Ci); and B, instant carboxylation efficiency (iCE) of naturally-colored cotton (Gossypium hirsutum) genotypes 93 days after sowing. Distinct lowercase letters indicate significant differences among cotton plant genotypes by Tukey's test, at $5 \%$ probability. Bars represent the standard error of the mean $(n=21)$.

Pesq. agropec. bras., Brasília, v.53, n.6, p.746-755, June 2018 DOI: $10.1590 / \mathrm{S} 0100-204 X 2018000600011$ 
(Table 3), only for fiber productivity and plume cotton mass. Furthermore, salinity management strategies caused significant effects $(\mathrm{p}<0.01)$ on $\mathrm{Fm}, \mathrm{Fv}, \mathrm{Fv} /$ Fm, fiber productivity, and plume cotton mass. The unfolding of the factor management strategies $x$ genotype revealed significant effects only for plume cotton mass at 113 DAS.

There were no significant differences for Fo when salt stress was applied during the distinct phenological stages evaluated (Table 4). This result indicates that the exposure of plants to salinized irrigation water during the phenological stages did not affect the integrity of the complex light receptor of photosystem II (FS II) in naturally-colored cotton, which may be related to tolerance to salinity, as reported in other studies (Oliveira et al., 2014; Dias et al., 2016).
The mean grouping tests performed for maximum fluorescence as affected by the salinity management strategies (Table 4) indicated that $\mathrm{A}_{1} \mathrm{~B}_{1} \mathrm{C}_{1}$ was statistically superior; however, plants subjected to $\mathrm{A}_{2} \mathrm{~B}_{1} \mathrm{C}_{2}$ received $1,771.63$ electrons per quantum, not differing from those irrigated with low-salinity water during their life cycle. Similar tendencies were obtained for Fo and Fm; therefore, salt stress in $\mathrm{A}_{2} \mathrm{~B}_{1} \mathrm{C}_{2}$ did not impair quinone $\mathrm{A}$ photoreduction or electron flow among photosystems (Tatagiba et al., 2014).

During the flowering and fructification phenological stages (Table 4), plants irrigated with highly salinized water, subjected to $\mathrm{A}_{1} \mathrm{~B}_{2} \mathrm{C}_{1}$ and $\mathrm{A}_{1} \mathrm{~B}_{2} \mathrm{C}_{2}$, exhibited $\mathrm{Fv}$ values of $1,346.03$ and $1,308.815$ electrons per quantum, respectively, which were 9.41 and $14.43 \%$

Table 3. Analysis of variance for initial fluorescence (Fo), maximum fluorescence (Fm), variable fluorescence (Fv), and quantum yield of photosystem II (Fv/Fm) in naturally-colored cotton (Gossypium hirsutum) plants at 93 days after sowing (DAS), as well as plume fiber productivity (FP) and plume cotton mass (Plcotton) at 113 DAS according to salinity management strategies and genotypes ${ }^{(1)}$.

\begin{tabular}{|c|c|c|c|c|c|c|c|}
\hline \multirow[t]{2}{*}{ Source of variation } & \multirow[t]{2}{*}{ DF } & \multicolumn{6}{|c|}{ Mean square } \\
\hline & & Fo & Fm & Fv & $\mathrm{Fv} / \mathrm{Fm}$ & FP & Plcotton \\
\hline Management strategy (MS) & 6 & $239.36^{\mathrm{ns}}$ & $52,058.04 * *$ & $52,301.79 * *$ & $0.0003^{* *}$ & $5.59 * *$ & $4,710.77 * *$ \\
\hline Genotype (G) & 2 & $440.23^{\mathrm{ns}}$ & $4144.10^{\mathrm{ns}}$ & $2,224.53^{\mathrm{ns}}$ & $0.00006^{\mathrm{ns}}$ & $147.64 * *$ & $4,618.92 * *$ \\
\hline MS x G & 12 & $168.77^{\mathrm{ns}}$ & $6236.48^{\mathrm{ns}}$ & $5,621.43^{\text {ns }}$ & $0.00007^{\mathrm{ns}}$ & $0.74^{\mathrm{ns}}$ & $136.25^{*}$ \\
\hline Block & 2 & $1,761.32^{\text {ns }}$ & $189,882.37^{\mathrm{ns}}$ & $23,207.75^{\mathrm{ns}}$ & $0.0007^{\mathrm{ns}}$ & $0.30^{\mathrm{ns}}$ & $6.39^{\mathrm{ns}}$ \\
\hline Error & 40 & 167.53 & $3,985.76$ & $3,216.02$ & 0.00004 & 0.98 & 55.58 \\
\hline CV (\%) & & 4.48 & 3.73 & 4.04 & 0.77 & 3.66 & 11.55 \\
\hline Mean & & 288.941 & 1691.460 & $1,403.465$ & 0.828 & 27.196 & 64.55 \\
\hline
\end{tabular}

${ }^{(1)} \mathrm{DF}$, degrees of freedom; and CV, coefficient of variation. * and $* *$ Significant by the F-test, at 5 and $1 \%$ probability, respectively. ${ }^{\text {ns Nonsignificant. }}$

Table 4. Mean test for initial fluorescence (Fo), maximum fluorescence (Fm), variable fluorescence (Fv), and quantum yield of the photosystem II (Fv/Fm) in cotton (Gossypium hirsutum) plants under different salinity management strategies at 93 days after sowing ${ }^{(1)}$.

\begin{tabular}{lcccc}
\hline Management strategy & Fo & Fm & Fv & Fv/Fm \\
\hline $\mathrm{A}_{1} \mathrm{~B}_{1} \mathrm{C}_{1}$ & $292.74 \pm 10.54 \mathrm{a}$ & $1,814.48 \pm 47.32 \mathrm{a}$ & $1,529.70 \pm 40.88 \mathrm{a}$ & $0.839 \pm 0.004 \mathrm{a}$ \\
$\mathrm{A}_{2} \mathrm{~B}_{1} \mathrm{C}_{1}$ & $293.66 \pm 6.38 \mathrm{a}$ & $1,679.29 \pm 35.17 \mathrm{~b}$ & $1,385.63 \pm 34.69 \mathrm{~b}$ & $0.824 \pm 0.004 \mathrm{c}$ \\
$\mathrm{A}_{1} \mathrm{~B}_{2} \mathrm{C}_{1}$ & $285.77 \pm 9.09 \mathrm{a}$ & $1,628.70 \pm 31.84 \mathrm{c}$ & $1,346.03 \pm 27.13 \mathrm{c}$ & $0.825 \pm 0.004 \mathrm{c}$ \\
$\mathrm{A}_{1} \mathrm{~B}_{1} \mathrm{C}_{2}$ & $285.77 \pm 8.90 \mathrm{a}$ & $1,685.00 \pm 34.05 \mathrm{~b}$ & $1,399.22 \pm 32.51 \mathrm{~b}$ & $0.829 \pm 0.005 \mathrm{~b}$ \\
$\mathrm{~A}_{2} \mathrm{~B}_{1} \mathrm{C}_{2}$ & $293.25 \pm 4.32 \mathrm{a}$ & $1,771.63 \pm 41.04 \mathrm{a}$ & $1,478.37 \pm 43.51 \mathrm{a}$ & $0.833 \pm 0.005 \mathrm{~b}$ \\
$\mathrm{~A}_{2} \mathrm{~B}_{2} \mathrm{C}_{1}$ & $282.18 \pm 7.67 \mathrm{a}$ & $1,658.81 \pm 32.38 \mathrm{~b}$ & $1,376.48 \pm 25.73 \mathrm{~b}$ & $0.829 \pm 0.003 \mathrm{~b}$ \\
$\mathrm{~A}_{1} \mathrm{~B}_{2} \mathrm{C}_{2}$ & $292.18 \pm 4.32 \mathrm{a}$ & $1,602.29 \pm 19.55 \mathrm{c}$ & $1,308.81 \pm 22.21 \mathrm{c}$ & $0.818 \pm 0.003 \mathrm{~d}$ \\
\hline
\end{tabular}

(1) Means followed by distinct lowercase letters indicate significant differences among salinity management strategies by Scott-Knott's test, at $5 \%$ probability, and followed by distinct uppercase letters indicate significant differences among cotton plant genotypes by Tukey's test, at $5 \%$ probability. Number \pm standard error. $A_{1}, B_{1}, C_{1}$, no salinity during the vegetative, flowering, and fructification stages, respectively; and $A_{2}, B_{2}, C_{2}$, salinity during the vegetative, flowering, and fructification stages. 
lower than those obtained for plants without salt stress during the cycle in $\mathrm{A}_{1} \mathrm{~B}_{1} \mathrm{C}_{1}$.

The quantum efficiency of photosystem II for plants under salt stress in the $\mathrm{A}_{2} \mathrm{~B}_{1} \mathrm{C}_{1}$ and $\mathrm{A}_{2} \mathrm{~B}_{2} \mathrm{C}_{1}$ management strategies decreased an average of $1.70 \%$, compared with plants irrigated with low-salinity water during the entire cycle in $\mathrm{A}_{1} \mathrm{~B}_{1} \mathrm{C}_{1}$ (Table 4). However, the most significant reduction was found in $\mathrm{A}_{1} \mathrm{~B}_{2} \mathrm{C}_{2}$, in which $\mathrm{Fv}$ showed 0.818 electrons per quantum, as
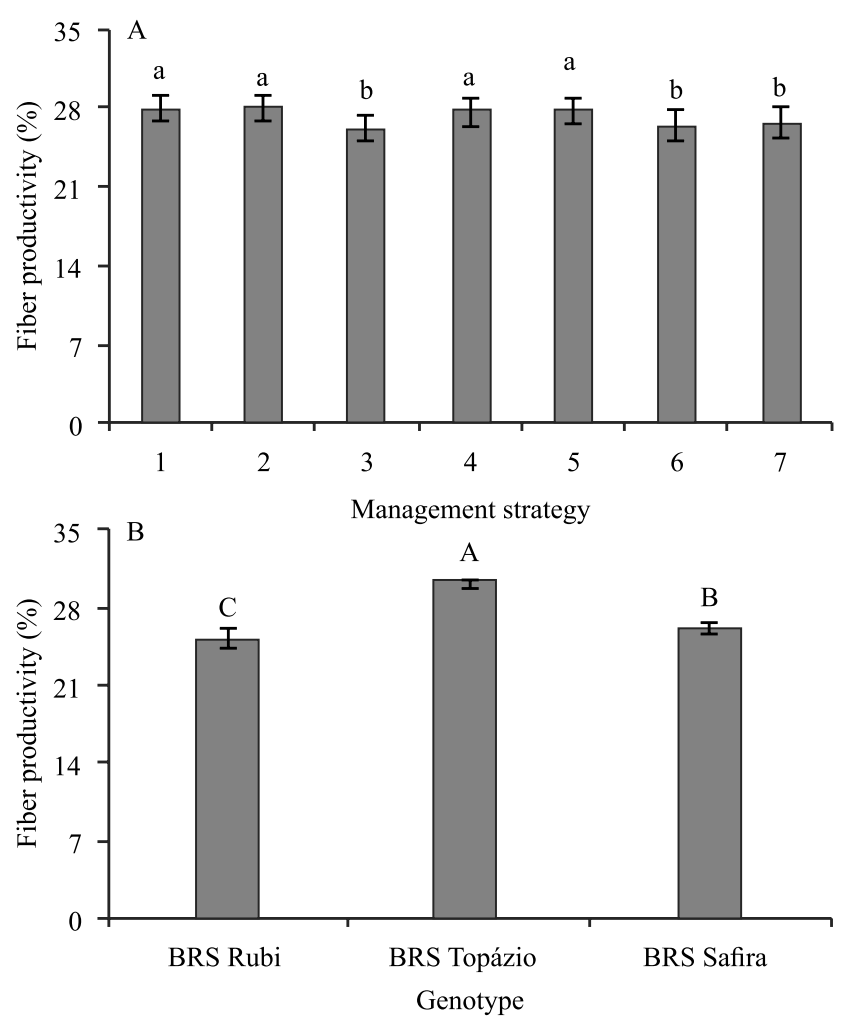

Figure 3. Means related to the fiber productivity of naturally-colored cotton (Gossypium hirsutum) plants under different salinity management strategies during phenological stages (A) and among genotypes (B) at 113 days after sowing. Distinct lowercase letters indicate significant differences among salinity management strategies by Scott-Knott's test, at 5\% probability, and distinct uppercase letters indicate significant differences among cotton plant genotypes by Tukey's test, at 5\% probability. Bars represent the standard error of the mean for management strategies $(n=9)$ and genotypes $(n=21) .1, A_{1} B_{1} C_{1} ; 2, A_{2} B_{1} C_{1} ; 3, A_{1} B_{2} C_{1}$; 4, $\mathrm{A}_{1} \mathrm{~B}_{1} \mathrm{C}_{2} ; 5, \mathrm{~A}_{2} \mathrm{~B}_{1} \mathrm{C}_{2} ; 6, \mathrm{~A}_{2} \mathrm{~B}_{2} \mathrm{C}_{1}$; and $7, \mathrm{~A}_{1} \mathrm{~B}_{2} \mathrm{C}_{2}$, where $\mathrm{A}_{1}$, $\mathrm{B}_{1}, \mathrm{C}_{1}$ represent no salinity during the vegetative, flowering, and fructification stages, and $\mathrm{A}_{2}, \mathrm{~B}_{2}, \mathrm{C}_{2}$, salinity during the vegetative, flowering, and fructification stages. observed for gas exchange. Decreases in $\mathrm{Fv} / \mathrm{Fm}$ were also reported for peanut (Arachis hypogaea L.) and safflower (Carthamus tinctorius L.) plants (Correia et al., 2009; Çulha Erdal \& Çakirlar, 2014); however, the decreases verified in the present study did not cause the degradation of the photosynthetic apparatus, since the obtained values were above 0.75 (Silva et al., 2014).

Fiber productivity decreased in $6.34,5.41$, and $4.65 \%$ in the $\mathrm{A}_{1} \mathrm{~B}_{2} \mathrm{C}_{1}, \mathrm{~A}_{2} \mathrm{~B}_{2} \mathrm{C}_{1}$, and $\mathrm{A}_{1} \mathrm{~B}_{2} \mathrm{C}_{2}$ management strategies, respectively, compared with $\mathrm{A}_{1} \mathrm{~B}_{1} \mathrm{C}_{1}$, when plants were subjected to salt stress during the flowering and fructification stages (Figure 3 A). It should be highlighted that there was an average recovery of $27 \%$ in fiber productivity in plants subjected to salt stress in $\mathrm{A}_{2} \mathrm{~B}_{1} \mathrm{C}_{1}, \mathrm{~A}_{1} \mathrm{~B}_{1} \mathrm{C}_{2}$, and $\mathrm{A}_{2} \mathrm{~B}_{1} \mathrm{C}_{2}$. However, Khorsandi \& Anagholi (2009) verified that irrigation with $10 \mathrm{dS} \mathrm{m}^{-1}$ during the vegetative stage negatively affected cotton productivity during the end of the cycle. Among the analyzed genotypes, 'BRS Topázio' presented the highest fiber productivity (30.21\%), which was 16.49 and $13.46 \%$ greater than that of 'BRS Rubi' and 'BRS Safira', respectively, regardless of the adopted salinized water management strategy (Figure 3 B).

The highest plume cotton mass values were observed for the 'BRS Topázio' genotype at 113 DAS (Table 5). Regarding salinity management, the highest means were obtained for the $A_{1} B_{1} C_{1}$ and $A_{2} B_{1} C_{1}$ strategies.

Table 5. Mean test for the unfolding of the interaction between cotton (Gossypium hirsutum) plant genotypes and management strategies for plume cotton mass at 113 days after sowing ${ }^{(1)}$.

\begin{tabular}{lccc}
\hline \multirow{2}{*}{$\begin{array}{l}\text { Management } \\
\text { strategy }\end{array}$} & \multicolumn{3}{c}{ Genotype } \\
\cline { 2 - 4 } & BRS Rubi & BRS Topázio & BRS Safira \\
\hline $\mathrm{A}_{1} \mathrm{~B}_{1} \mathrm{C}_{1}$ & $84.33 \pm 5.53 \mathrm{aB}$ & $125.33 \pm 3.54 \mathrm{aA}$ & $87.66 \pm 3.32 \mathrm{aB}$ \\
$\mathrm{A}_{2} \mathrm{~B}_{1} \mathrm{C}_{1}$ & $73.33 \pm 2.51 \mathrm{aB}$ & $114.66 \pm 1.04 \mathrm{aA}$ & $81.00 \pm 6.87 \mathrm{aB}$ \\
$\mathrm{A}_{1} \mathrm{~B}_{2} \mathrm{C}_{1}$ & $54.66 \pm 4.07 \mathrm{bC}$ & $90.33 \pm 3.05 \mathrm{bA}$ & $72.00 \pm 2.29 \mathrm{aB}$ \\
$\mathrm{A}_{1} \mathrm{~B}_{1} \mathrm{C}_{2}$ & $44.66 \pm 2.02 \mathrm{cB}$ & $63.00 \pm 3.27 \mathrm{cA}$ & $49.66 \pm 0.57 \mathrm{bAB}$ \\
$\mathrm{A}_{2} \mathrm{~B}_{1} \mathrm{C}_{2}$ & $40.33 \pm 3.54 \mathrm{cB}$ & $62.66 \pm 2.56 \mathrm{cA}$ & $43.33 \pm 2.56 \mathrm{bB}$ \\
$\mathrm{A}_{2} \mathrm{~B}_{2} \mathrm{C}_{1}$ & $42.00 \pm 6.94 \mathrm{cB}$ & $68.00 \pm 3.60 \mathrm{cA}$ & $43.00 \pm 3.60 \mathrm{bB}$ \\
$\mathrm{A}_{1} \mathrm{~B}_{2} \mathrm{C}_{2}$ & $34.33 \pm 2.25 \mathrm{cA}$ & $45.66 \pm 1.60 \mathrm{dA}$ & $35.66 \pm 4.07 \mathrm{bA}$ \\
\hline
\end{tabular}

${ }^{(1)}$ Means followed by distinct lowercase letters indicate significant differences among salinity management strategies by Scott-Knott's test, at $5 \%$ probability, and followed by distinct uppercase letters indicate significant differences among cotton plant genotypes by Tukey's test, at $5 \%$ probability. Number \pm standard error. $A_{1}, B_{1}, C_{1}$, no salinity during the vegetative, flowering, and fructification stages; and $A_{2}, B_{2}, C_{2}$, salinity during the vegetative, flowering, and fructification stages. 
It is important to emphasize that 'BRS Safira' plants irrigated with salinized water during flowering in $\mathrm{A}_{1} \mathrm{~B}_{2} \mathrm{C}_{1}$ showed the highest means of $72 \mathrm{~g}$ per plant; the $\mathrm{A}_{1} \mathrm{~B}_{1} \mathrm{C}_{2}, \mathrm{~A}_{2} \mathrm{~B}_{1} \mathrm{C}_{2}, \mathrm{~A}_{2} \mathrm{~B}_{2} \mathrm{C}_{1}$, and $\mathrm{A}_{1} \mathrm{~B}_{2} \mathrm{C}_{2}$ management strategies resulted in the lowest means.

The results obtained in the present study revealed that the effects of salinity on naturally-colored cotton production are related to stress during the flowering and production stages. Production decreases due to $\mathrm{ECW}$ increases may be attributed to lower water absorption by plants under salt stress because of the lower soil water potential, as concluded by Cordão Sobrinho et al. (2007). This was confirmed by the results of the present study, in which the effects of salinity were greater on gas exchange than on $a$ chlorophyll fluorescence, i.e., water restriction due to increased water salinity caused reductions in stomatal conductance, transpiration, and liquid photosynthesis, but did not cause irreversible damage to the photosynthetic apparatus, since the quantum yield values for photosystem II were over 0.75 , showing that ionic effects were less expressive.

\section{Conclusions}

1. Irrigation with salinized water significantly reduces gas exchange in naturally-colored cotton (Gossypium hirsutum) plants during the production stage, but increases plume cotton production in the vegetative stage.

2. Irrigation with salinized water during different phenological stages of naturally-colored cotton genotypes does not compromise the quantum yield of their photosystems.

3. Among the studied genotypes, 'BRS Topázio' stands out due to its higher fiber productivity and plume cotton production.

\section{Acknowledgments}

To Coordenação de Aperfeiçoamento de Pessoal de Nivel Superior (Capes), for scholarship granted to the first author; and to Embrapa Algodão, for providing the seeds.

\section{References}

ALBRECHT, L.P.; BRACCINI, A. de L. e; ÁVILA, M.R.; BARBOSA, M.C.; RICCI, T.T.; ALBRECHT, A.J.P. Aplicação de biorregulador na produtividade do algodoeiro e qualidade de fibra. Scientia Agraria, v.10, p.191-198, 2009. DOI: 10.5380/rsa. v10i3.14474.

ASHRAF, M.; ATHAR, H.R.; HARRIS, P.J.C.; KWON, T.R. Some prospective strategies for improving crop salt tolerance. Advances in Agronomy, v.97, p.45-110, 2008. DOI: 10.1016/ S0065-2113(07)00002-8.

AYERS, R.S.; WESTCOT, D.W. A qualidade da água na agricultura. 2.ed. Campina Grande: Ed. da UFPB, 1999. 153p. (Estudos FAO. Irrigação e Drenagem, 29).

CHEN, W.; HOU, Z.; WU, L.; LIANG, Y.; WEI, C. Effects of salinity and nitrogen on cotton growth in arid environment. Plant and Soil, v.326, p.61-73, 2010. DOI: 10.1007/s11104-008-9881-0.

CORDÃO SOBRINHO, F.P.; FERNANDES, P.D.; BELTRÃO, N.E. de M.; SOARES, F.A.L.; TERCEIRO NETO, C.P.C. Crescimento e rendimento do algodoeiro BRS-200 com aplicações de cloreto de mepiquat e lâminas de irrigação. Revista Brasileira de Engenharia Agrícola e Ambiental, v.11, p.284-292, 2007. DOI: $10.1590 /$ S1415-43662007000300007.

CORREIA, K.G.; FERNANDES, P.D.; GHEYI, H.R.; NOBRE, R.G.; SANTOS, T. da S. Crescimento, produção e características de fluorescência da clorofila $a$ em amendoim sob condições de salinidade. Revista Ciência Agronômica, v.40, p.514-521, 2009.

ÇULHA ERDAL, Ş; ÇAKIRLAR, H. Impact of salt stress on photosystem II efficiency and antioxidant enzyme activities of safflower (Carthamus tinctorius L.) cultivars. Turkish Journal of Biology, v.38, p.549-560, 2014. DOI: 10.3906/biy-1401-33.

DESINGH, R.; KANAGARAJ, G. Influence of salinity stress on photosynthesis and antioxidative systems in two cotton varieties. General and Applied Plant Physiology, v.33, p.221-234, 2007.

DIAS, A.S.; NOBRE, R.G.; LIMA, G.S. de; GHEYI, H.R.; PINHEIRO, F.W.A. Crescimento e produção de algodoeiro de fibra colorida cultivado em solo salino-sódico e adubação orgânica. Irriga, v.1, p.260-273, 2016. Edição Especial Grandes Culturas. DOI: 10.15809/irriga.2016vln1p260-273.

DONG, H.; KONG, X.; LUO, Z.; LI, W.; XIN, C. Unequal salt distribution in the root zone increases growth and yield of cotton. European Journal of Agronomy, v.33, p.285-292, 2010. DOI: 10.1016/j.eja.2010.08.002

FERREIRA, D.F. Sisvar: a computer statistical analysis system. Ciência e Agrotecnologia, v.35, p.1039-1042, 2011. DOI: 10.1590/ S1413-70542011000600001.

GRATAN, S.R.; GRIEVE, C.M.; POSS, J.A.; ROBINSON, P.H.; SUAREZ, D.L.; BENES, S.E. Evaluation of salt-tolerant forages for sequential water reuse systems. I. Biomass production. Agricultural Water Management, v.70, p.109-120, 2004. DOI: 10.1016/j.agwat.2004.04.010.

JAFRI, A.Z.; AHMAD, R. Reproductive physiology of cotton under saline conditions. In: AHMAD, R.; MALIK, K.A. (Ed.). Prospects for saline agriculture. Dodrecht: Springer Science, 2002. p.209-214. (Tasks for vegetation science, v.37). DOI: 10.1007/978-94-017-0067-2_23.

KHORSANDI, F.; ANAGHOLI, A. Reproductive compensation of cotton after salt stress relief at different growth stages. Journal of Agronomy and Crop Science, v.195, p.278-283, 2009. DOI: 10.1111/j.1439-037X.2009.00370.x.

KONRAD, M.L.F.; SILVA, J.A.B. da; FURLANI, P.R.; MACHADO, E.C. Trocas gasosas e fluorescência da clorofila em 
seis cultivares de cafeeiro sob estresse de alumínio. Bragantia, v.64, p.339-347, 2005. DOI: 10.1590/S0006-87052005000300004.

LETEY, J.; FENG, G.L. Dynamic versus steady-state approaches to evaluate irrigation management of saline waters. Agricultural Water Management, v.91, p.1-10, 2007. DOI: 10.1016/j. agwat.2007.02.014.

LIMA, G.S. de; DIAS, A.S.; GHEYI, H.R.; SOARES, L.A. dos A.; NOBRE, R.G.; SÁ, F.V. da S.; PAIVA, E.P. de. Emergence, morpho-physiology and flowering of colored-fiber cotton (Gossypium hirsutum L.) submitted to different nitrogen levels and saline water stress irrigation. Australian Journal of Crop Science, v.11, p.897-905, 2017. DOI: 10.21475/ajcs.17.11.07.pne587.

LIMA, G.S. de; OLIVEIRA, L.D. de; GHEYI, H.R.; SOARES, L.A. dos A.; LACERDA, C.F. de; SANTOS, J.B. dos; ARAÚJO, B.M. de. Cultivation of colored cotton irrigated with saline water under potassium and nitrate/ammonium fertilization. African Journal of Agricultural Research, v.11, p.32-39, 2016. DOI: 10.5897/AJAR2015.10540.

MAXWELL, K.; JOHNSON, G.N. Chlorophyll fluorescence: a practical guide. Journal of Experimental Botany, v.51, p.659668, 2000. DOI: 10.1093/jexbot/51.345.659.

NEVES, A.L.R.; LACERDA, C.F. de; GUIMARÃES, F.V.A.; HERNANDEZ, F.F.F.; SILVA, F.B. da; PRISCO, J.T.; GHEYI, H.R. Acumulação de biomassa e extração de nutrientes por plantas de feijão-de-corda irrigadas com água salina em diferentes estádios de desenvolvimento. Ciência Rural, v.39, p.758-765, 2009. DOI: $10.1590 / \mathrm{S} 0103-84782009005000014$.

NOBRE, R.G.; LIMA, G.S. de; GHEYI, H.R.; SOARES, L.A. dos A.; SILVA, A.O. da. Crescimento, consumo e eficiência do uso da água pela mamoneira sob estresse salino e nitrogênio. Revista Caatinga, v.27, p.148-158, 2014.

NOVAIS, R.F. de; NEVES J.C.L.; BARROS N.F. de. Ensaio em ambiente controlado. In: OLIVEIRA, A.J. Métodos de pesquisa em fertilidade do solo. Brasília: Embrapa-SEA, 1991. p.189-253. (EMBRAPA-SEA. Documentos, 3).

OLIVEIRA, L.L. de P.; DIAS, N. da S.; MEDEIROS, L.C.; FERREIRA, L.L. Tolerância de cultivares de algodão (Gossypium hirsutum) à salinidade da água de irrigação. Agropecuária Científica no Semiárido, v.10, p.66-71, 2014. DOI: 10.30969/acsa. v10i2.539.

OLIVEIRA, L.L.P.; DIAS, N.S.; FARIAS, W.C.; MEDEIROS, L.C.; FERREIRA L.L. Tolerância de cultivares de algodão (Gossypium hirsutum) à salinidade da água de irrigação. Revista Verde de Agroecologia e Desenvolvimento Sustentável, v.8, p.232-237, 2013.

PANDYA, D.H.; MER, R.K.; PRAJITH, P.K.; PANDEY, A.N. Effect of salt stress and manganese supply on growth of barley seedlings. Journal of Plant Nutrition, v.27, p.1361-1379, 2005. DOI: $10.1081 /$ PLN-200025835.

PEREIRA, E.R. de L. Tolerância de genótipos do algodão colorido ao estresse salino. 2012. 105p. Dissertação (Mestrado) - Universidade Estadual da Paraíba, Campina Grande.
RADY, M.M.; ABD EL-MAGEED, T.A.; ABDURRAHMAN, H.A.; MAHDI, A.H. Humic acid application improves field performance of cotton (Gossypium barbadense L.) under saline conditions. The Journal of Animal \& Plant Sciences, v.26, p.487-493, 2016.

ROSALES, M.A.; OCAMPO, E.; RODRÍGUEZ-VALENTÍN, R.; OLVERA-CARRILLO, Y.; ACOSTA-GALLEGOS, J.; COVARRUBIAS, A.A. Physiological analysis of common bean (Phaseolus vulgaris L.) cultivars uncovers characteristics related to terminal drought resistance. Plant Physiology and Biochemistry, v.56, p.24-34, 2012. DOI: 10.1016/j.plaphy.2012.04.007.

SANTOS, H.G. dos; JACOMINE, P.K.T.; ANJOS, L.H.C. dos; OLIVEIRA, V.A. de; LUMBRERAS, J.F.; COELHO, M.R.; ALMEIDA, J.A. de; CUNHA, T.J.F.; OLIVEIRA, J.B. de. Sistema brasileiro de classificação de solos. 3.ed. Brasília: Embrapa, 2013. 353p.

SANTOS, J.B. dos; GHEYI, H.R.; LIMA, G.S. de; XAVIER, D.A.; CAVALCANTE, L.F.; CENTENO, C.R.M. Morfofisiologia e produção do algodoeiro herbáceo irrigado com águas salinas e adubado com nitrogênio. Comunicata Scientiae, v.7, p.86-96, 2016. DOI: 10.14295/cs.v7i1.1158.

SHAHEEN, H.L.; SHAHBAZ, M. Salt-induced effects on some key morpho-physiological attributes of cotton (Gossypium hirsutum L.) at various growth stages. Soil \& Environment, v.31, p.125-133, 2012.

SHIMAZAKI, K-I..; DOI, M.; ASSMANN, S.M.; KINOSHITA, T. Light regulation of stomatal movement. Annual Review of Plant Biology, v.58, p.219-247, 2007. DOI: 10.1146/annurev. arplant.57.032905.105434.

SILVA, A.A.R. da; LIMA, G.S. de; AZEVEDO, C.A.V. de; SOARES, L.A. dos A.; GHEYI, H.R.; OLIVEIRA, R.C. de. Potassium fertilization in the cultivation of colored cotton irrigated with saline water. Revista Brasileira de Engenharia Agrícola e Ambiental, v.21, p.628-633, 2017. DOI: 10.1590/18071929/agriambi.v21n9p628-633.

SILVA, L. de A.; BRITO, M.E.B.; SÁ, F.V. da S.; MOREIRA, R.C.L.; SOARES FILHO, W. dos S.; FERNANDES, P.D. Mecanismos fisiológicos em híbridos de citros sob estresse salino em cultivo hidropônico. Revista Brasileira de Engenharia Agrícola e Ambiental, v.18, p.S1-S7, 2014. Suplemento. DOI: 10.1590/1807-1929/agriambi.v18nsupps1-s7.

TATAGIBA, S.D.; MORAES, G.A.B.K.; NASCIMENTO, K.J.T.; PELOSO, A. de F. Limitações fotossintéticas em folhas de plantas de tomateiro submetidas a crescentes concentrações salinas. Revista Engenharia na Agricultura, v.22, p.138-149, 2014. DOI: 10.13083/1414-3984.v22n02a05.

ZHANG, L.; MA, H.; CHEN, T.; PEN, J.; YU, S.; ZHAO, X. Morphological and physiological responses of cotton (Gossypium hirsutum L.) plants to salinity. PLoS ONE, v.9, e112807, 2014. DOI: 10.1371/journal.pone.0112807.

ZHANG, L.; ZHANG, G.; WANG, Y.; ZHOU, Z.; MENG, Y.; CHEN, B. Effect of soil salinity on physiological characteristics of functional leaves of cotton plants. Journal of Plant Research, v.126, p.293-304, 2013. DOI: 10.1007/s10265-012-0533-3.

Received on June 5, 2017 and accepted on September 4, 2017

Pesq. agropec. bras., Brasília, v.53, n.6, p.746-755, June 2018 DOI: $10.1590 / \mathrm{S} 0100-204 \mathrm{X} 2018000600011$ 